\title{
Knowledge Management Capabilities of Lead Firms in Innovation Ecosystems
}

\author{
Chander Velu \\ Institute for Manufacturing \\ Department of Engineering \\ 17 Charles Babbage Road \\ Cambridge CB3 OFS \\ University of Cambridge \\ United Kingdom \\ Tel: +44 (0)1223 765879 \\ Fax: +44 (0)1223 464217 \\ e-mail: c.velu@eng.cam.ac.uk
}

Acknowledgements: The author would like to thank Jan Heide and Sriya Iyer for helpful discussions. The author would also like to thank the Editor and the anonymous reviewers for their helpful comments on earlier versions of this paper. 


\title{
Knowledge Management Capabilities of Lead Firms in Innovation Ecosystems
}

\begin{abstract}
Knowledge management is a key capability for innovation. Prior research has typically conceptualized and examined knowledge management capabilities as a property of an individual firm or business unit. More recently, however, the locus of competition and innovation has started to shift from the individual firm to firms working together as an ecosystem. In light of these changing realities, we explicate a set of capabilities that are built, maintained, and exercised by the lead firm in order to enhance innovation within ecosystems. We highlight three knowledge management capabilities: (1) knowledge acquisition, (2) knowledge sharing, and (3) knowledge utilization. Drawing on open and closed action strategies firms use to foster team-based innovation, we develop propositions for the knowledge management capabilities of the lead firm. Our approach highlights three salient tensions that arise from team based innovation: autonomy-control, dissent-consent and uncertainty-certainty. We highlight how the three tensions need to be managed across knowledge management capabilities in order to increase the rate of innovation of the ecosystem. In doing so, we contribute to the evolving marketing literature on sensing and responding in ecosystems in order to provide customers with superior value. We discuss the implications for both managers and theory.
\end{abstract}

Keywords: Knowledge Management Capabilities, Lead Firm, Innovation Ecosystems 


\section{Introduction}

Marketing scholars have articulated the importance of capabilities that help firms to identify changes in their environment and respond by providing customers with superior value (see Day 1994; Day 2011). The demands of contemporary changes in the environment due to globalization, rapid changes in the technological landscape, and a blurring of industry borders render such capabilities a high priority for firms. In such ambiguous environments, for a single firm to understand the changes taking place and to respond to the opportunities in a timely manner is a tall order. In these hypercompetitive markets, in which time-to-market foretells success, innovation costs are soaring, and revenues are under pressure, the need to distribute risks and exploit expertise, customer, and market knowledge across the spectrum requires a new set of organizational capabilities (Iansiti and Levien 2004). Therefore, firms are increasingly collaborating with customers, suppliers, and even competitors to form an ecosystem to drive innovation and growth (Day 2011). One of the key capabilities to drive innovation and growth is the provision of leadership guiding how to sense, coordinate, and respond to new knowledge among partner firms in such an ecosystem (Teece 2007). In this paper, we develop the key knowledge management capabilities for the lead firm in the ecosystem by using the duality principle of open and closed action strategies to foster team-based innovation (Gebert, Boerner and Kearney 2010).

An ecosystem exists when firms are interdependent on one another to achieve a common goal; ecosystems often display both cooperation and competition among partner firms (Iansiti and Levien 2004; Moore 2006; Brandenburger and Nalebuff 1997). Innovation ecosystems enable a collection of assets to be leveraged jointly by member firms in order to help stimulate

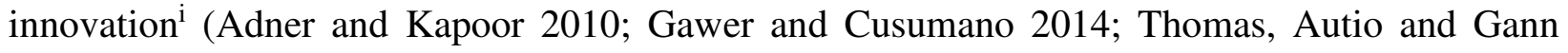


2014). These collections of assets could be technologies, knowledge, or skills that comprise a platform $^{\text {ii }}$ (Zahra and Nambisan 2011). Therefore, "the platform becomes a vehicle for ecosystem partners to leverage one another's capabilities as well as to enhance their individual innovation and financial performance",iii (Zahra and Nambisan 2011, p. 6). Hence, an innovation ecosystem consists of intentional communities of actors whose individual activities depend on and share the collective fate of the whole ecosystem (Moore 2006; Iansiti and Levien 2004). Recently, a number of authors have highlighted that the network structure among firms would be usefully enhanced as an ecosystem (Adner and Kapoor 2010; Adner 2006) to account better for community orientation (Snow et al. 2011), growing interdependence, and the symbiotic nature of relationships between the firm and its external stakeholders (Moore 2006) and the firm as resource integrator (Vargo and Lusch 2004). Firms such as Apple and Facebook have offered recent potent examples of innovation ecosystem. They have both been extremely successful in leveraging the collective technologies, knowledge, and skills of their ecosystems by stimulating innovation from external developers (Allison 2008).

Innovation ecosystems typically have a firm that acts as the leader arising from informal authority as a result of expertise, resources, or bargaining power based on asymmetric dependence among partner firms (Gulati, Puranam and Tushman 2012). Studies have examined the role of such lead firms in stimulating and shaping the ecosystem ${ }^{\text {iv }}$ (Adner and Kapoor 2010; Williamson and de Meyer 2012), as well as governance of the ecosystem (Smith and Lewis 2011; Wareham, Fox and Giner 2014). However, additional lead firm capabilities are required in order for such ecosystems to sense market shifts, create new knowledge, and respond to fastchanging environments (Prahalad and Krishnan 2008). Lead firms in innovation ecosystems have to develop superior knowledge-processing capabilities (Weick 1976) in order to identify market 
requirements, bring together partners, and stimulate innovation across increasingly complex supply chains (Heide 1994; Hult 2011; Vargo and Lusch 2004). Moreover, the recent marketing literature has emphasized the importance of capabilities to build relationships across firm boundaries in order to exchange knowledge, shape the market, and create the associated value for customers in a networked world (Day 2011; Heide and Wathne 2006; Lusch, Vargo and Tanniru 2010). However, studies articulating the key knowledge -management capabilities of the lead firm in innovation ecosystems are still at a nascent stage.

We add to the extant studies on leadership in ecosystems and extend the theorized capabilities the lead firm uses in knowledge management to stimulate innovation. Previous studies have emphasized the importance of paradox in stimulating innovation; however, these studies have mainly been in the context of a single firm (see Seo et al. 2004; Smith, Binns and Tushman 2010) or governance of the ecosystem (Smith and Lewis 2011; Wareham, Fox and Giner 2014) but have not addressed the capabilities of the lead firm in an ecosystem. Our focus is on explicating the knowledge management capabilities of the lead firm. We highlight three capabilities, namely knowledge acquisition, knowledge sharing, and knowledge utilization, that lead firms use to improve the rate of innovation of the ecosystem. In particular, our dependent variable is performance in terms of the rate of innovation of the ecosystem, and our unit of analysis is the knowledge management capabilities of the lead firm. An increase in the rate of innovation could imply an increased rate of new product/service/business model development.

Our approach highlights three salient tensions that arise from team based innovation: autonomy-control, dissent-consent and uncertainty-certainty. We highlight how these three tensions need to be managed across the knowledge management capabilities in order to increase 
the rate of innovation of the ecosystem. In particular, we build on the work of Wareham, Fox and Giner (2014) that highlights the need to manage tensions in ecosystem governance, along with the study by Gerbert, Boerner and Kearney (2010) that argues for harnessing the opposing forces inherent in team based innovation. We propose the use of open and closed action strategies for knowledge generation and knowledge integration to elaborate on the capabilities needed (Gebert, Boerner and Kearney 2010). The open and closed action strategies highlight the benefits of duality via delegative and directive leadership in order to achieve the right balance for sustained innovation.

We contribute to the literature in two ways. First, we contribute to the evolving marketing literature on sensing and responding in networked markets in order to provide customers with superior value by explicating the knowledge management capabilities of the lead firm in stimulating innovation within an ecosystem. In doing so, the paper responds to the call for more conceptual papers in marketing (Yadav 2010). Second, the work advances our understanding of how knowledge management tensions in innovation ecosystems need to be managed by providing direction whilst not stifling creativity, in order to stimulate innovation.

In the next section, we discuss the conceptual foundations of our research. Then in the following section, we develop the key knowledge management capabilities of the lead firm in an ecosystem. Finally, we discuss the managerial and theoretical implications before summarizing our conclusions. 


\section{Conceptual foundations}

Capabilities and innovation ecosystems

A key challenge for firms operating within an innovation ecosystem concerns their capability to understand customer needs continually: to convene the competencies of the ecosystems in order to serve customers effectively (Vargo and Lusch 2011). Innovation ecosystems reshape and permeate markets and hierarchies by coordinating innovation across complementary knowledge commons in a co-evolutionary manner. Knowledge commons refers to information, data, and content that is owned, managed, and used collectively by a community (Hess and Ostrom 2007). Ecosystems are therefore organized not only to share knowledge through a commons that is collectively and privately exploited (von Hippel and von Krog 2003) but also to facilitate pooled and direct linkages among member firms to expand the knowledge commons (Stabell and Fjeldstad 1998; Snow et al. 2011). To do so, lead firms in innovation ecosystems need to develop specific capabilities if they are to capture the potential value of collaboration.

In a fast-changing world, organizations' capabilities need to help them anticipate changes, shape the market, and respond to opportunities accordingly. Day (1994) argues that capabilities to sense and respond to the market can be usefully classified into three types: outside-in, inside-out, and spanning processes. Outside-in capabilities enable firms to connect the processes to the external environment and enable them to compete by anticipating market requirements ahead of competitors. Inside-out capabilities are activated by market requirements, competitive challenges, and external opportunities. Spanning capabilities help firms to integrate the inside-out and outside-in capabilities. Although these processes were formulated for the general capabilities of a firm, they can be equally applied to the management of innovation. In this context, the functions of the capabilities can be seen either to exploit an existing opportunity 
or to explore new opportunities. Day (2011) argues for firms to develop adaptive marketing capabilities, which have an outside-in orientation that is customer driven and emphasizes exploration. We propose that firms operating in an ecosystem need to have outside-in, spanning, and inside-out processes to enhance exploration and hence innovation. The capabilities of the lead firm to orchestrate the partner firms lie at the heart of the innovation performance of the ecosystem.

Knowledge is a key factor in driving innovation (Sanchez and Mahoney 1996). Knowledge management refers to a set of systematic and disciplined actions that an organization can take to obtain the greatest value from the knowledge that it has. We extend such a conceptualization of the lead firm within an innovation ecosystem. We explicate the elements of capabilities of the lead firm to foster a more integrated and collaborative approach to knowledge acquisition, sharing, and utilization in a rapidly changing environment to stimulate innovation (Tiwana 2002).

Knowledge and innovation ecosystem

Studies on knowledge management in an innovation ecosystem setting have focused on knowledge exploration, retention, and exploitation (Lichtenthaler 2011). The literature has recognized that such knowledge management needs to be organized internally as well as externally; that is, both within the firm's organizational boundaries as well as transcending the firm's boundaries with the external partners. The focus of the extant literature, however, has been primarily on the knowledge management capabilities of the individual firm. However, the competitive need to innovate in order to make superior returns suggests the desire to share knowledge that otherwise would not be available to any one firm internally (see Dahlquist and Griffith 2015). In addition, knowledge ecosystems have been recognized to be concentrated 
around central actors, but the role of such actors in encouraging innovation is not well articulated (Clarysse, Wright, Bruneel and Mahajan 2014). Moreover, knowledge is argued to be contextualized and tied to the usage context or "value-in-use" (see Lusch, Vargo and Tanniru 2010). Therefore, innovation calls for knowledge brokering, whereby knowledge is moved from one context to another in order to generate knowledge and facilitate new products and services. Such knowledge brokering calls for firms to be organized as an innovation ecosystem. Teamwork is important among firms for such knowledge brokering in order to both generate and integrate knowledge to create value for the firms and customers in a collaborative network (Sheremata 2002). Teamwork in turn requires communication.

Thus, we posit that teamwork is important for such innovation ecosystems to function effectively because they typically exhibit four characteristics evident in teams (De Rond 2008). First, teams have a common goal. Second, teams usually have a team leader and a set of members. Third, teams usually need to collaborate by sharing information and communicating them between the members as each brings a different set of skills or knowledge albeit with some overlaps. Fourth, team members often display an element of competition with each other in order to be recognized and perhaps become the next team leader. The combination of cooperation as well as competition creates a tension that needs to be managed for the team to perform effectively.

In this paper, we therefore use open and closed action strategies as applied to team innovation as a basis for knowledge generation and knowledge integration to develop the knowledge management capabilities of the lead firm in the innovation ecosystem (Gebert, Boerner and Kearney 2010; Sheremata 2002). We explicate the knowledge management capabilities of the lead firm in order to stimulate innovation of the ecosystem, such as the rate of 
product/service innovation, process innovation, and business model innovation. The elements of team innovation developed by Gebert, Boerner and Kearney (2010) involve managing the tension between open and closed action strategies. Open action strategies entail delegative leadership, while closed action strategies entail directive leadership (Jackson et al. 2003).

Open and closed action strategies manifest through three opposing forces that arise from anthropological, social, and epistemological dimensions respectively (Gebert, Boerner and Kearney 2010). The first is the anthropological dimension, which relates to the extent to which people need autonomy versus control. On the one hand, autonomy provides decentralization and empowerment in order to expand the range of possibilities (Brown and Eisenhardt 1997). Such open action strategies need to be combined with closed action strategies in order to curtail freedom; these closed action strategies are based on time and budget constraints, centralized control, and frequent feedback (Lewis et al. 2002). The second is the social dimension, which relates to the interaction among people that could result in a degree of consensus versus dissent. On the one hand, facilitating open communication, debate, and disagreement necessitates a variety of views and is part of the open action strategies (Reagans and Zuckerman 2001). Such open action strategies need to be combined with closed action strategies such as promoting informal communication, collectivist culture, and team homogenizing in order to enhance consensus potential (Obstfeld 2005). The third is the epistemological dimension, which relates to the nature of knowledge being inherently uncertain and hence requiring a process of continual revision. Such uncertainty contrasts with knowledge that displays a degree of certainty and hence does not require corrective inputs and continual revision. On the one hand, fostering knowledge exchange with external entities generates new knowledge and might create uncertainty, which is an open action strategy. On the other hand, promoting internal team communication and utilizing 
existing knowledge consolidates new and existing knowledge and promotes certainty, which is a closed action strategy (Katz 1982; Keller 1994). We provide a summary of the concepts in Table 1 and also provide examples of the concepts of open/closed action strategies across the three dimensions.

\section{Table 1 about here.}

We describe these forces in detail in the next section and apply them to team innovation dynamics to explicate the capabilities of the lead firm within an ecosystem setting. We build on the work of Wareham, Fox and Giner (2014) that discusses how to manage tensions in ecosystem governance, along with the study by Gerbert, Boerner and Kearney (2010) that articulates how to manage the opposing forces inherent in team based innovation. In particular, we bring together the concept of tensions in ecosystem governance with team-based innovation and apply it to knowledge management capabilities of the lead firm in innovation ecosystems in order to develop our propositions. We provide a conceptual framework in Figure 1 that summarizes our approach.

Figure 1 about here.

\section{Knowledge management capabilities within innovation ecosystems}

\section{Capabilities for Knowledge Acquisition}

Knowledge management capabilities critically rely on a firm's ability to acquire and shape meaningful knowledge on emerging market trends and competitor moves. Firms, therefore, need to search their environment to identify the salient signals amid a vast pool of external cues (Day and Schoemaker 2004). As the inflow of signals is growing at an ever-faster rate, individual firms are increasingly overwhelmed by the quantity, as well as quality, of incoming information. 
To alleviate their resource constraints, firms have begun to establish ecosystems for collaborative means of acquiring and shaping knowledge (Achrol and Kotler 1999). The acquisition and shaping of knowledge is an outside-in capability. To acquire and shape insightful market knowledge, organizations have to leave their comfort zones to search their respective environments for clues about customer trends, competitor actions, and technological shifts (Kohli and Jaworski 1990; Slater and Narver 1995). As technological and spatial boundaries diminish in salience, such environment scanning needs to become ever more proactive, distant, and comprehensive (Chesbrough 2003). Organizations are thus required to screen both the core and the periphery of their environments if they are to gain novel market and technological insights ahead of their competitors (Day and Schoemaker 2004; Teece 2007). Firms' ecosystems enable them to generate knowledge internally through the combination of information among member firms, as well as distant and external search efforts.

We next discuss how the tensions arising from autonomy vs. control, dissent vs. consensus, and uncertainty vs. certainty provide the duality to enable knowledge management capabilities in knowledge acquisition, sharing, and utilization respectively. Autonomy is the empowerment of firms in an ecosystem to make decisions individually, which is balanced by the tension to control, whereby the lead firm takes decision collectively for the ecosystem. Dissent is where firms are encouraged to disagree with each other, which is balanced by the tension of having to reach agreement to move things forward. Uncertainty involves embracing areas where little is known and being comfortable with the unknown, which is balanced by the tension to want certainty where there is fuller knowledge of the situation in hand. 
Autonomy vs. control

Autonomy New knowledge could be gathered from recombining knowledge from within, outside, and across firm boundaries (Rosenkopf and Nerkar 2001; Katila and Ahuja 2002). Collaborative knowledge acquisition greatly increases the likelihood of a serendipitous recombination of previously unconnected knowledge elements (Luca and Atuahene-Gima 2007). One source of knowledge is through the novel use of excess resources. Scholars have argued about how resources are employed or the functionality of the resource that creates competitive advantage (Penrose 1959; Wernerfelt 1984). Penrose (1959) argued that resources need to be combined in order to create value. However, resources are indivisible and, therefore, the combination of resources used always creates "excess resources." For example, the specialization and division of labor implies that the utilization of skills and capital available might not always match exactly, resulting in excess resources. The search for novel uses for these excess resources may expand the opportunity set for the firm, which contributes to innovation and growth possibilities (Penrose 1959). In a collaborative environment, the capacity to recombine these excess resources increases with the number of firms in the ecosystem.

The lead firm can increase the possibility of knowledge generation by adopting an open action strategy. Such an open action strategy manifests itself through delegative leadership of the lead firm by encouraging increasing diversity of firms to join the ecosystem. Potential partner firms might have different criteria and willingness to participate in an ecosystem as the expected benefits could vary for these firms. Therefore, the lead firm needs to design the terms of joining the ecosystem as a partner firm to cater for these differences in order to encourage requisite variety in knowledge generation. One way to achieve this is for the lead firm to embrace 
structural openness by granting potential partner firms a high level of autonomy regarding whether to join the ecosystem (Nambisan and Sawhney 2011).

Structural openness implies more open network boundaries, whereby more members can join the network. Such structural openness could be implemented with stratified tiering of the partners. Stratified tiering is implemented by outlining a number of different membership tiers for potential partner firms. Firms need to fulfill these specified criteria in order to join an appropriate tier of membership. Such stratified tiering of partners encourages firms with different levels of resources to decide for themselves the degree to which they are willing to engage with the ecosystem partners. Therefore, stratified tiering encourages firms with different criteria and willingness to engage to join the ecosystem and, hence, provides a more and varied degree of knowledge and resources than would otherwise be possible with only a single criterion for being part of the ecosystem. The increased knowledge and resources from ecosystem partner firms provides the stimulus for further knowledge generation. Hence, delegative leadership by the lead firm in terms of membership of the ecosystem through stratified tiering helps the ecosystem to develop niche areas of complementary partners in order to add value to the existing ecosystem partners in terms of knowledge generation.

Control Merely providing delegative leadership with great autonomy for the exploration of new ideas will not yield desirable results. This is because autonomy with no directives will render team members very expansive with little coordination (Sheremata 2002). This might result in each firm creating its own rules about what type of knowledge is generated and given access to the partners (Mathieu et al. 2000). Such a policy without restrictions on access to the knowledge generated could create disincentives for partner firms to participate effectively in the knowledge generation process. Therefore, the lead firm also needs to adopt closed action strategies. Such a 
closed action strategy involves directive leadership in terms of specifying the rules for resource commitment and knowledge generation across each of the stratified tiers of membership. Prior research has shown that firms in a collaborative setting will not engage in knowledge generation activities if there are ex-ante concerns about how the knowledge would be used (Heiman and Nikerson 2004). The lead firm needs to set some core principles for knowledge appropriation in order to encourage knowledge generation among partner firms. For example, intellectual property rules should specify what types of constellations of partner firms' knowledge generated can be shared among other partners that did not contribute to such knowledge generation. The lead firm could specify that partner firms that were not engaged with the intellectual property knowledge generation could benefit from the knowledge generated depending on the needs of that partner firm and the ecosystem collectively. For example, in a design and manufacturing ecosystem, the manufacturers would need access to new developments in process technologies whilst a fabless partner that relies on manufacturers to produce the product might get access to design and applications technologies (Leten et al. 2013). Such specified rules on membership should enable the lead firm to exercise graduated control over the different tiers of partnership across the ecosystem in order to provide incentives for partner firms to generate new knowledge. Based on the preceding discussion, we posit the following proposition:

P1a: The lead firm will increase the rate of innovation within its ecosystem by combining autonomy via open access membership through stratified tiering with control via implementing graduated controls across the tiered membership in knowledge -acquisition activities. 
Dissent vs. consensus

Dissent Research from various fields has shown that key benefits accrue from having diversity in team composition, due to the variance in perspectives and work approaches that different members of the team can bring (see Chatman et al. 1998). Fostering task-related diversity by assembling firms for the ecosystem with different characteristics in terms of age, size, function, and sector focus could add to the diversity of knowledge that is generated. Firms with such different characteristics will exhibit experiential and cognitive diversity and hence facilitate the clarification, organization, and combination of different sources of information to generate new knowledge. Moreover, an ecosystem consisting of diverse firms is likely to tap into a wider network of other firms to generate diverse knowledge. However, such diverse knowledge is likely to generate a variety of perspectives and also conflicts and dissentions, which in turn could increase the range of knowledge generated. Therefore, the lead firm can increase the possibility of knowledge generation by adopting an open action strategy in order to encourage dissent.

The lead firm can facilitate such dissent and, hence, knowledge generation by organizing specific workshops whereby firms with different characteristics meet to discuss technology and market-related themes. Such physical meetings could also be complemented with virtual meetings on the Web or through a secure online medium. Such meetings to explore ideas could facilitate new knowledge acquisition by generating discussion and dissent among participating firms.

Consensus Having a diverse set of firms as part of the ecosystem can generate significant dissent without a common agreement of the relevant knowledge that needs to be generated. Therefore, the open action strategy that encourages diversity needs to be tempered by a closed action strategy that fosters a collectivist culture. Fostering a collectivist culture involves the lead firm 
making salient the firms' commonalities regarding goals and objectives in order to promote ecosystem cohesion (Beal et al. 2003). This would cause the firms in the ecosystem to perceive one another as in-group rather than out-group members and, hence, be more likely to encourage willingness to consent (Alper et al. 2000).

In order to foster a common vision for the ecosystem, the lead firm needs to articulate responsibilities to the tiered partners to facilitate discussion in the workshops and online community forums and to help identify issues that are key to the collective good of the ecosystem. Partner firms in higher stratified tiers typically commit to provide more resources and knowledge to the ecosystem and hence are more likely to also have a more holistic view of the benefits accruing to the ecosystem from any specific knowledge that is generated, compared to firms in lower stratified tiers. Therefore, the lead firm should award higher tiered partner firms the responsibility for deciding on more critical issues compared to lower tiered partner firms. The lead firm, in turn, should provide direction about the types of knowledge that need to be generated when there is a major disagreement. Based on the preceding discussion, we posit the following proposition:

P1b: The lead firm will increase the rate of innovation within its ecosystem by combining dissent by bringing diverse partner firms together in order to interact face-to-face or through virtual communities with consensus by giving greater responsibilities to higher tiered partners to help identify issues that are key to the collective good of the ecosystem in knowledge acquisition activities. 


\section{Uncertainty vs. certainty}

Uncertainty Knowledge acquisition could be either internal or external to the ecosystem (Ancori et al. 2000). On the one hand, the ecosystem could generate new knowledge by recombining knowledge already existing among partner firms-internal knowledge generation. New knowledge is often generated by such recombination of knowledge that is already readily available among partner firm. On the other hand, ecosystem members could generate new knowledge by scanning the environment that is external to the firm-external knowledge generation. Knowledge acquisition based on external knowledge of the firms in the ecosystem is an open action strategy. Encouraging external team communication constitutes such a countervailing open action strategy. Firms need to connect with the external environment to allow their current knowledge to be updated and evolve. Such a process, although valuable, creates more uncertainty compared to internal knowledge generation. However, such openness to alternative views promotes new knowledge generation by making it more likely that firms will come up with new combinations of ideas (Ancona and Caldwell 1992).

The lead firm needs to encourage external knowledge acquisition through the use of technology and market scouts that are appointed among ecosystem firm employees. Some lead firms in the pharmaceuticals and telecommunications industries have adopted such an approach of appointing technology and market scouts among their employees (see Rohrbeck 2010; Slowinski, Hummel, Gupta \& Gilmont 2009). These technology and market scouts need to scan the external market for new ideas and opportunities and bring them back for discussion among the partner firms. External market knowledge could take the form of closer engagement with consumers, suppliers, and other third-party organizations such as universities and research 
institutes. Such an external scouting activity will result in increased uncertainty as, although it might be far from the knowledge base of the ecosystem, it enables new knowledge to be created.

Certainty However, if the open action strategies, such as promoting reliance on external knowledge, are not combined with closed action strategies based on internal knowledge generation, there might be too much uncertainty to generate any useful knowledge. Knowledge acquisition based on ecosystem firms' internal knowledge is a closed action strategy. Such a closed action strategy is important in order to consolidate the knowledge that is held among the firms. If the lead firm regards its knowledge as sufficient, it will rely primarily on the ecosystem's internal knowledge to recombine and hence act as the basis for knowledge acquisition. As a result it will be easier to define common goals and facilitate decision making regarding what is useful knowledge when external knowledge is combined with internal knowledge. Hence, leveraging internally generated knowledge contributes to a more certain environment for knowledge-acquisition activities.

The lead firm needs to provide a clear roadmap of the future evolution of the ecosystem in order to reduce uncertainty (see Carvalho, Fleury and Lopes 2013; Caetano, M. \& D.C. Amaral 2011). The lead firm can do so by developing such a roadmap, by ensuring that external knowledge generated by the technology and market scouts is appropriately combined with internal knowledge within the partner firms. For example, a technology roadmap could be developed for the ecosystem by the lead firm by understanding the technology trajectories of each of the partner firms and then combining that information with the externally sourced information about customer preferences and other market-related developments. ARM Holdings, one of the world's leading semiconductor intellectual property companies, adopts such an approach whereby it articulates its enabling technology or architecture to partner firms within its 
ecosystem, who use it to define their own technology roadmaps. ${ }^{\mathrm{V}}$ ARM Holdings is then able to work with the partner firms as well as potential customers to help shape the future requirements for microprocessors and hence, develop a technology roadmap for the ecosystem. The combination of external and internal knowledge reduces uncertainty by creating a common goal regarding the type of knowledge that needs to be generated. Based on the preceding discussion, we posit the following proposition:

P1c: The lead firm will increase the rate of innovation within its ecosystem by combining certainty through using internal information with uncertainty through sourcing external information in knowledge acquisition activities.

\section{Capabilities for knowledge sharing}

The sharing of knowledge is a spanning capability, as it requires information to be disseminated across the ecosystem. The diversity of skillsets and knowledge across the ecosystem of firms promotes innovation but at the same time creates problems, as knowledge boundaries must be overcome to enable knowledge sharing. Studies have shown that organizations live in different worlds with different logics of action (Cyert and March 1963; Dougherty 2006). Therefore, to overcome such logics of action, knowledge sharing is a key capability of the lead firm in an innovation ecosystem linking previous knowledge acquisition and subsequent utilization processes.

\section{Autonomy vs. control}

Autonomy It is only by bridging the spatial and temporal distance between knowledge sharing and use that social entities can benefit fully from previous knowledge acquisition activities. Effective knowledge sharing is all the more essential for innovation ecosystems, where 
geographical, technological, and epistemological boundaries between partner firms tend to be even more pronounced than within individual firms (Dyer and Hatch 2006; Dyer and Singh 1998). Therefore, disseminating knowledge through inter-organizational knowledge transfer and learning is a critical enabler of innovation (Itami and Nishino 2010). Value is created and distributed across partnering firms through processes of inter-organizational knowledge transfer across the ecosystem between firms who are incentivized to share knowledge. Such knowledge transfer takes place in multiple directions, as roles and relationships change through partnerships that allow knowledge transfer to take place. There are two types of knowledge that need to be transferred (Richard and Devinney 2005). First, component knowledge relates to how the components of a new product or service proposition need to work, for example, the technical aspects of a product or marketing innovations related to the channel to market. The second is architectural knowledge, which relates to how the component systems interlink and work together (Henderson and Clark 1990). An open action strategy by the lead firm involves decisional openness (Nambisan and Sawhney 2011). Decisional openness implies greater potential for each firm within the ecosystem to influence and shape the decisions related to resources and ideas being generated. The lead firm needs to exercise decisional openness in enabling partner firms to disseminate component knowledge freely across the ecosystem. This is because the individual firms are those closest to understanding the component knowledge based on their respective expertise.

Control Market knowledge often emerges in one part of the organization, while being required to inform decision making in another. Consequently, novel market insights need to be shared and discussed such that they become meaningful throughout the organization (Day 2011). Knowledge sharing routinely yields a constant and substantial inflow of complex data likely to 
contain both noise and vital signals of emerging market or technological trends (Day and Schoemaker 2004). It is only by separating signal from noise, and by finding coherent patterns in apparent chaos, that such raw data can be translated into knowledge that is meaningful to decision makers (Day 1994; Sinkula 1994; Teece 2007). Given the ever-growing quantity and complexity of market data that is potentially available, organizations have to excel at sorting, classifying, filtering, and simplifying market data (Cyert and March 1963; Day 1994). The lead firm will be able to see more of the patterns of knowledge being generated across the ecosystem in order to develop the architectural knowledge required to better understand how the components of the new proposition fits together. Such architectural knowledge relates to how the components of a new product or service proposition fits together with the overall platform architecture. Although each partner firm might have a good understanding of the knowledge related to the components, they might only have a partial understanding of the platform architecture to enable these propositions to be delivered to the market. The role of the lead firm is to disseminate the knowledge related to such a platform architecture to the partner firms so that all members of the ecosystem have a common understanding and can coordinate their actions. The lead firm should embrace a closed action strategy by disseminating such architectural knowledge and hence directing the ecosystem in terms of the type of component knowledge to be disseminated (Davis and Eisenhardt 2011). Based on the preceding discussion, we posit the following proposition:

P2a: The lead firm will increase the rate of innovation within its ecosystem by combining autonomy through embracing decisional openness for component knowledge dissemination with control through dissemination of architectural knowledge in knowledge sharing activities. 
Dissent vs. consensus

Dissent The allocation of scarce managerial attention to a particular issue is a vital precursor for strategic action (March and Shapira 1987; Ocasio 1997). It provides the internal legitimacy required to mobilize broad support and to dedicate substantial resources to find appropriate solutions (Dutton et al. 1997; Dutton et al. 2001). Decision makers, thus, must be persuaded of the strategic relevance of a specific market insight if an appropriate response is to be developed (Teece 2007). It is important to encourage dissent among firms in order to ensure that all angles of the issue are discussed openly and debated before being disseminated through the ecosystem. Disagreement among partner firms helps trigger knowledge exchange by exploring opposing opinions and, hence, re-evaluation of the status quo. Studies show that dissent increases divergent thinking and creativity only when there is reflexivity (De Dreu 2002). Reflexivity happens when the partner firms are made to reflect consciously on strategies and objectives in order to process dissenting viewpoints. Such a reflexive process is needed to sort the good from the bad ideas and disseminate the former through the ecosystem.

The lead firm needs to enable debate and dissent among firms, which encourages an increased range of ideas and facilitates knowledge sharing about how best to pursue particular goals (Simons et al. 1999). However, the lead firm needs to embrace open action strategy by fostering reflexivity among partner firms, by getting them to overtly reflect upon the ecosystem's objectives, strategies, and processes and adapt them to the anticipated circumstances. The lead firm can build reflexivity among partner firms by getting them to review frequently the ecosystem objectives, discuss the methods used by the member firms to disseminate knowledge, and reflect regularly on whether the member firms are working effectively in knowledge dissemination activities. The lead firm could encourage both individual and group reflexivity to 
encourage dissent through increased divergent thinking among partner firms. Individual reflexivity includes activities where each partner firm is encouraged to reflect and communicate issues with the lead firm whist group reflectivity encourages the parent firms to collectively reflect and communicate issues. The relevant issues could relate to knowledge concerning tasks as well as knowledge concerning individual partner firm responsibilities.

Consensus Merely embracing open action strategy by encouraging debate and dissent will not yield desirable results, because debate and dissent alone could result in high levels of relationship and value conflicts (De Dreu and Weingart 2003). This in turn might result in dysfunctional conflicts among firms and decrease their willingness to accept alternative views (Bunderson and Sutcliffe 2002). Therefore, the lead firm needs to embrace closed action strategies. Such a closed action strategy involves consensus building among firms in the ecosystem, which fosters a collectivist culture (Chatman et al. 1998). Fostering a collectivist culture ensures ecosystem cohesion, as well as building trust within the network (Rousseau et al. 1998). The lead firm needs to develop an organizational and technological infrastructure for the ecosystem (Gawer and Cusumano 2008) in order to build trust and mitigate risk, which can adversely influence knowledge transfer (Easterby-Smith, Lyles and Tsang 2008). Building trust and mitigating risks is particularly important in the case where the lead firm encourages individual and group reflexivity among partner firms.

In order to build trust, the lead firm needs to manage power relations and asymmetries between itself and the partner firms in the ecosystem, which is critical to sustaining their symbiotic relationships. This ensures that firms in the ecosystem develop a common social identity and are more willing to consent to both the dissemination and receipt of knowledge from other firms in the ecosystem. The lead firm must assure other partner firms that it will not use its 
superior information advantage for its own benefit to capture value. The lead firm needs to share information on the interfaces but also to keep the inner workings of a particular firm's contribution to the ecosystem, which could have been obtained through the individual reflexivity initiative, proprietary and non-transparent so that partner firms will be willing to disseminate knowledge more readily (Williamson and de Meyer 2012). Based on the preceding discussion, we posit the following proposition:

P2b: The lead firm will increase the rate of innovation within its ecosystem by combining dissent through building reflexivity among partner firms with consensus through providing assurance of not leveraging power from information asymmetries in knowledge sharing activities.

\section{Uncertainty vs. certainty}

Uncertainty The knowledge sharing process itself could generate new knowledge as firms combine their own knowledge with the information received from other partner firms. Standards are required in order to combine information and resources for knowledge sharing. Such standards should allow for flexibility in sense making and, hence, have the characteristics of fuzzy rules, where there is "room for interpretation" (Avadikyan et al. 2001). The lead firm in the ecosystem needs to embrace an open action strategy by developing fuzzy rules for knowledge interpretation as it is shared across the ecosystem. Such fuzzy rules or standards are required to handle complex new knowledge that needs to be transferred. Such complexity often arises when the benefits of the value added from the new knowledge is uncertain and the investment, risks, and rewards to the partner firms are ambiguous. In such cases, the lead firm will need to work with the partner firms in order to create a set of standards for the dissemination of knowledge given the complexity of a particular situation. This clearly creates uncertainty for the partners. 
However, as their overriding principle such fuzzy rules should have fairness in the dissemination of knowledge. For example, the lead firm could specify fuzzy rules in the case of group reflexivity exercises where the members of the ecosystem meet collectively, such as "meet as often as required in order to interpret and disseminate knowledge." In addition, the group reflexivity exercises should provide guidance on knowledge sharing without providing specific strategies for doing so. Such fuzzy rules are useful for solving technical problems when knowledge is being disseminated.

Certainty Knowledge sharing requires standards across the ecosystem in order to have a common language with which to analyze data and communicate the knowledge transfer effectively. Standardization enables better comparison of data in order to leverage coordination for knowledge sharing. Such standards, therefore, have the characteristics of codified rules (Avadikyan et al. 2001). The lead firm in the ecosystem needs to embrace a closed action strategy by developing codified standards for knowledge that are fairly routine. The codified standards could take the form of specification of precise formats for technology roadmaps for partner firms to follow in developing their own versions or defining standards for complex design specifications for new product or service specifications for partner firms to adopt. Such codified rules help reduce transaction costs and, hence, uncertainty in sharing knowledge between partner firms. Both fuzzy and codified rules need to be in place to manage the duality in knowledge sharing. Based on the preceding discussion, we posit the following proposition:

P2c: The lead firm will increase the rate of innovation within its ecosystem by combining uncertainty through adopting fuzzy rules with certainty through adopting codified rules in knowledge sharing activities. 
Capabilities for knowledge utilization

To capture emerging opportunities, organizations must utilize knowledge to create effective new value propositions for customers (Day 2011). In particular, they need to translate new market insights into innovative product or service offerings supported by the appropriate business models (Han, Kim and Srivastava 1998; Hurley and Hult 1998; Teece 2010). Given the resource requirements and the systemic nature of innovation, however, the individual firm faces challenges in developing a timely and effective response (Dodgson, Gann and Salter 2006). To alleviate such problems, firms favor collaborations to develop response strategies that rely on joint new product/service development and business model innovation (Achrol and Kotler 1999; Chesbrough 2003).

Autonomy vs. control

Autonomy Utilization relates to responsiveness to new knowledge. Such utilization of knowledge involves modifications to organizations' product or service portfolio by altering, discontinuing, or developing novel offerings (Atuahene-Gima 1995). Firms' abilities to respond to novel market and technology insights with new product or service offerings depend as much on the ecosystem's ability to design an appropriate business model (Teece 2007). A firm's business model is of vital importance in that it defines the customer value proposition, the means of creating and delivering value, as well as the revenue architecture for value capture (Achrol 1991; McGrath 2010; Velu and Stiles 2013). A business model, hence, describes the general approach to doing business and sketches the route to market for a novel product or service offering. Firms need to be able to redesign their business models in response to novel market knowledge in order to be able to create and capture value. 
The lead firm needs to enable partner firms to develop new business models by combining their respective assets. The asset combination might involve data, analytical tools, sales and distribution capabilities, and intellectual property among others. The lead firm should provide considerable autonomy to each partner firm to decide on how to recombine their assets with other partner firms in order to develop the new business model. In particular, the lead firm should enable partner firms to leverage one another's assets so that they can facilitate innovation to the business model. The lead firm can enable the sharing of assets by fostering a heterarchical system that legitimizes multiple skills and types of knowledge among partner firms without privileging one over the other (Crumley 1995). In a heterarchical system, authority is determined by knowledge and function that is specific to the decision that needs to be made rather than predetermined in advance (McCulloh 1945). Hence, a heterarchical system has many centers whereby firms within the ecosystem are unranked (non-hierarchical) or where they have the potential to be ranked a number of different ways depending on the skills required to make a decision (Hedlund 1986). The combination of assets based on which group of partner firms might have the appropriate expertise enables new business models to emerge that would be required to commercialize the new product or service offering.

Control The creation of novel business models to take the product or service propositions to market involves experimentation (Sosna et al. 2012). Such experimentation in the design of the business model needs to be carried out by not combining too many components simultaneously but to use assets configurations that have shown to work previously in order to recombine them into new business models (Denrell, Fang and Winter 2003; Velu 2015). Therefore, the lead firm needs to provide guidance regarding the overall architecture of the new business model. The lead firm is well positioned to do so as it develops the platform architecture to enable the asset 
configurations of partner firms to be combined to create new business models. The lead firm could do this by acting as an integrator, by envisioning and clarifying the architecture of the new business model (Nambisan and Sawhney 2011). The lead firm needs to focus on the assets that can be used by various partner firms, as well as the interlinkages among them, in order to enhance the ability of ecosystem members to develop the appropriate business models. The lead firm should provide the horizontal links among partner firms in the ecosystem that allow different combinations of firms to cooperate whilst optimizing different success criteria for the firms when designing an appropriate business model. Therefore, through such a process of designing the platform architecture and ensuring linkages enables the lead firm to provide some control over the recombination of assets used by the partner firms in the creation of the new business model. Based on the preceding discussion, we posit the following proposition:

P3a: The lead firm will increase the rate of innovation within its ecosystem by combining autonomy through enabling partner firms to decide on how to recombine their assets to develop the new business model with control through acting as an integrator to design the platform architecture in knowledge utilization activities.

\section{Dissent vs. consensus}

Dissent Responding with a new product or service proposition often requires an appropriate business model. However, knowing which business model to use is often difficult, and it needs to be created for the specific situation of the marketplace. Business models have both a cognitive and economic dimension (Velu and Stiles 2013). The cognitive dimension defines the cognitive frame or mental model of the perception of the business approach held by the senior management. The economic dimension defines the revenue and cost architecture in order to 
make a return on capital. Senior management often rely on the cognitive frame or dominant logic of the existing business model in order to deliver a new product or service proposition. On the one hand, such a cognitive view of the dominant logic of the business model is necessary in order to focus and serve existing markets. On the other hand, when there are shifts in technology and market forces, a new dominant logic might be necessary.

The lead firm needs to encourage partner firms to challenge the dominant logic of the existing business models. The lead firm should foster dissent among partner firms to express different views about why a new dominant logic might be necessary. Such dissent is important in order to establish strategic compatibility between the product/service proposition and the business approach to delivering new propositions (Casadesus-Masanell and Ricart 2010). The lead firm needs to encourage partner firms in the ecosystem to use analogical reasoning or conceptual combinations from other industries and contexts in order to renew the existing dominant logic (Martins, Rindova and Greenbaum 2015). Analogical reasoning is the use of knowledge contained in a schema from one domain (e.g., business model design from another industry) in order to interpret information in another domain (e.g., the new business model design for the ecosystem). Conceptual combination in contrast is a cognitive process through which a target concept is combined with a modifier/source concept in order to create a new business model design. The lead firm needs to help partner firms in the ecosystem to identify the source concept for the new business model design, identify similarities and differences, and modify them accordingly in order to develop the dominant logic of the new business model design. Such a process might create dissent among partner firms as their dominant logic might be challenged and hence, this can be considered to be an open action strategy. 
Consensus Merely embracing an open action strategy by encouraging dissent in challenging the existing dominant logic could result in potentially detrimental conflicts across the partner firms. The focal firm needs to facilitate the building of a collective commitment to help converge on a well-conceived, new dominant logic. The focal firm needs to display both adaptive and decisive leadership in steering the partner firms to arrive at a decision about a new business model design. The focal firm could do this by surfacing any underlying cognitive biases and assumptions that might be inherent among the firms and reconciling any differences of opinion. The focal firm also needs to display decisional leadership by making decisions about the design of the new business model for experimentation where differences prevail after an attempt to reconcile them. Such a process creates consent via a closed action strategy. Based on the preceding discussion, we posit the following proposition:

P3b: The lead firm will increase the rate of innovation within its ecosystem by combining dissent through encouraging renewal of the dominant logic of the existing business model with consensus through reconciling differences in the cognitive aspects of the business model design and providing decisive leadership when differences prevail in knowledge utilization activities.

\section{Uncertainty vs. certainty}

Uncertainty Combinatory innovation within innovation ecosystems is all the more important as innovations become increasingly systemic, consisting of numerous interdependent components integrated via shared platforms (Teece 2007). The creation of new business models requires the recombination of existing established subsystems or proven business models, which can come from the various partner firms within the ecosystem or by grafting in from external sources (Denrell, Fang and Winter 2003). In such a context, individual firms often find it difficult to 
experiment with new business models, as they require coordinated change across the many systemic elements of the business (Johnson, Christensen and Kagermann 2008). Such a change is difficult and often avoided, as it requires management either to disrupt or cannibalize simultaneously the existing revenue stream for a potentially uncertain stream in the future (Teece 2007).

The lead firm needs to encourage the grafting of new business models externally in order to help design new business models. Such a process might involve either bringing in a new partner that has the suitable business model or borrowing the principles of a new business model design and incorporating them into the combination of business models that exist within the partner firms. Such new business models would create uncertainty among partner firms within the ecosystem, who are less familiar with them. This is an open action strategy by the lead firm to create uncertainty.

Certainty On the other hand, merely creating uncertainty through grafting business models from the outside might result in confusion and difficulty in terms of conducting a planned experimentation of the new business model. This might be due to a lack of understanding among partner firms of the interdependencies of the new business model, as well as its strengths and weaknesses. Therefore, the lead firm needs to curtail such uncertainties by acting as the overall architect in managing the risks, educating the partner firms of the overall interdependencies and also managing a process of tapered transition (see Doz and Kosonen 2010). The lead firm needs to do so by ensuring that as many as possible of the partner firms' existing and well-proven business models and processes are leveraged in the process of grafting in any new business models. In addition, the lead firm should help surface and share assumptions among the partner firms about their objectives and aspirations in order to build a sense of unity. Creating a sense of 
continuous dialogue and a supportive environment in which partner firms can experiment would facilitate the reduction of ambiguity and also foster learning. The lead firm can do so by providing empathy and compassion to the partner firms and to provide a safety net whereby in case of failure the responsibility will be jointly shared. Such a process creates certainty via a closed action strategy. Based on the preceding discussion, we posit the following proposition:

P3c: The lead firm will increase the rate of innovation within its ecosystem by combining uncertainty through grafting business models from the outside with certainty through recombining existing business models of partner firms and acting as the overall architect in managing risks in knowledge utilization activities.

We provide a summary of the knowledge management capabilities of the lead firm in Table 2.

\section{Table 2 about here.}

\section{Discussion}

The management of innovation ecosystems calls for collaboration in mutual exchanges of knowledge, informal socializing, and internal monitoring based on rules that are less specified than those in a hierarchical system (Heide 1994). Research from managing common pool resources shows that a collaborative approach requires a polycentric governance model (Olstrom 2010). A polycentric model connotes that there are many centers of decision making that are interdependent in functioning as a system. Increasingly, firms are organizing themselves as an ecosystem in order to collaborate with one another in the knowledge-based economy with significant market and technological changes. Such an ecosystem of firms has many decision centers that are interdependent in order to deliver complex products and services. 
However, research shows that such an ecosystem works well when there is a common thread running through the firm and when leadership is provided by one of the partner firms (Iansiti and Levien 2004; Olstrom 2010). Typically such a thread is provided by a lead firm, which then acts to organize the ecosystem without necessarily directing all aspects of it. The lead firm has to engage simultaneously in delegative and directive leadership. On the one hand, delegative leadership promotes variety in acquisition, sharing, and utilization of knowledge among firms within the ecosystem (Gebert, Boerner and Kearney 2010). On the other hand, directive leadership reduces variety. The presence of such opposing forces is paradoxically crucial to the stability, development, and growth of the ecosystem. Although previous studies have emphasized the importance of paradox in stimulating innovation, the studies have mainly been in the context of a single firm (see Seo et al. 2004; Smith, Binns and Tushman 2010) or governance of the ecosystem (Smith and Lewis 2011; Wareham, Fox and Giner 2014).

Our approach highlights three salient tensions that arise from team based innovation, namely, autonomy-control, dissent-consent and uncertainty-certainty. We apply these three tensions to knowledge management capabilities in order to develop propositions to increase the rate of innovation of the ecosystem. In doing so, we build on the work of Wareham, Fox and Giner (2014) that highlights the need to manage tensions in ecosystem governance, along with the study by Gerbert, Boerner and Kearney (2010) that argues for harnessing the opposing forces inherent in team based innovation. We build on these extant studies by explicating the knowledge capabilities of the lead firm in the innovation ecosystem. We contribute to the evolving marketing literature on sensing and responding in networked markets in order to provide customers with superior value by explicating the knowledge management capabilities of the lead firm in stimulating innovation within an ecosystem. The study also advances our 
understanding of how knowledge management tensions need to be managed in innovation ecosystems by providing direction on the one hand, whilst not stifling creativity on the other, in order to stimulate innovation. Next we discuss the managerial and theoretical implications of our findings.

\section{Managerial implications}

The main managerial implication is for the lead firm to evaluate each of the three knowledge management processes to ensure that there are both open and closed action strategies present and that they maintain a healthy balance across the two opposing forces. These would involve developing the individual knowledge management capabilities across the anthropological, social, as well as epistemological dimensions, whilst ensuring that the positive effects of the opposing forces are brought to the surface and also curtailing any undesired effects.

Knowledge acquisition The lead firm, by adopting open access membership through stratified tiering, increases variety and, hence, directly enhances knowledge acquisition. On the other hand, implementing graduated controls across the tiered membership enables the lead firm to provide overall direction in terms of knowledge acquisition. As part of the knowledge acquisition, the lead firm needs to bring diverse partner firms together in order to interact faceto-face or through virtual communities, whilst articulating responsibilities to the tiered partners to help identify issues that are key to the collective good of the ecosystem. Finally, the lead firm needs to encourage knowledge acquisition from external sources whilst stimulating internal knowledge generation. These strategies for knowledge acquisition by the lead firm balance higher autonomy via open action strategy with adequate controls via closed action strategy.

Greater autonomy increases the generation of new ideas, which in turn prevents existing rules and regulations from becoming too embedded and rigid (Dougherty 2006). Hence, the 
indirect benefits of open action strategy, by breaking any repressive nature of the existing rules, such as membership tiering, communications protocol among partner firms, and appointment of technology/market scouts, curtail the undesired effects of closed action strategy. On the other hand, closed action strategies, through their directive leadership, facilitate better coordination among firms and, therefore, shape any knowledge that is being acquired. Therefore, the indirect benefit of closed action strategy via the establishment of rules prevents any destabilizing effects of unfocused knowledge acquisition by firms in the ecosystem. Consequently, the simultaneous enactment of both delegative and directive leadership by the ecosystem enables effective knowledge acquisition. Such a duality-based approach improves collaborative knowledge management and hence, enhances the innovation of the ecosystem.

Knowledge sharing The lead firm, by embracing decisional openness for component knowledge dissemination, increases variety and, hence, directly enhances knowledge sharing. On the other hand, implementing control through the dissemination of architectural knowledge enables the lead firm to provide overall direction in terms of the design of the new proposition and its interlinkages. In order to further enhance knowledge sharing, the lead firm needs to build reflexivity among partner firms whilst providing assurance of not leveraging power from information asymmetries in knowledge sharing activities. Finally, the lead firm needs to encourage knowledge sharing by adopting fuzzy standards to encourage informal learning whilst adopting codified standards for more formal sharing of knowledge. These strategies for knowledge sharing by the lead firm balance open action strategy with closed action strategy.

The open action strategy of autonomy, creating dissent and uncertainty in knowledge sharing, increases the diversity of the types of knowledge to be shared. However, the greater diversity of knowledge implies that firms are more willing to accept alternative views because 
they feel that their view has been tabled and discussed (Kaplan 2008; Velu and Stiles 2013). Therefore, the indirect benefits of an open action strategy, by breaking any defensive viewpoints among firms, curtail the undesired effects of a closed action strategy. On the other hand, closed action strategies, through their emphasis on consent, provide high levels of cohesion among firms. Such cohesion increases the willingness of agreement among firms about the types of knowledge to disseminate. Therefore, the indirect benefit of closed action strategy via the encouragement of consent prevents any destabilizing effects of dysfunctional behavior such as dissent among firms in the ecosystem. Consequently, the simultaneous enactment of both open and closed action strategies by the ecosystem enables effective knowledge sharing.

Knowledge utilization The lead firm, by devolving provision of the components of the new business model to partner firms, increases variety and, hence, directly enhances knowledge utilization. On the other hand, acting as an integrator across the components enables the lead firm to provide overall direction in terms of the design of the new business model. In order to further enhance knowledge utilization, the lead firm needs to encourage renewal of the dominant logic of the existing business model whilst reconciling differences in the cognitive aspect of the business model design and providing decisive leadership when differences prevail. Finally, the lead firm needs to graft business models from outside whilst encouraging partner firms to recombine existing business models and acting as the overall architect to manage risks. These strategies for knowledge utilization by the lead firm balance open action strategy with closed action strategy.

The new customer value proposition seeking the efforts of firms will often be affected by strategic inertia (Hannan and Freeman 1984). For these reasons, decision makers tend to favor strategic choices that lead to less risky and disruptive outcomes (Teece 2007). In an attempt to 
prevent the obsolescence of current resources and business models, preference will be given to stability over change (Christensen and Bower 1996; Henderson and Clark 1990).

The open action strategy of embracing autonomy, creating dissent and uncertainty, increases the ability of the lead firm to question existing value creation perspectives and accept new propositions. Moreover, the higher diversity of knowledge implies that firms are more willing to accept new propositions. Therefore, the indirect benefits of open action strategy, by breaking any preconceived mental models with respect to business model design among firms, curtail the undesired effects of closed action strategy. On the other hand, closed action strategies, through control, consent, and certainty, provide high levels of cohesion for exploration. Such cohesion increases the willingness of firms to experiment. Therefore, the indirect benefit of a closed action strategy prevents any destabilizing effects of confusion due to excessive experimentation and uncertainty (Bresman 2010). Consequently, the simultaneous enactment of both open and closed action strategies by the lead firm enables the effective utilization of knowledge.

Lead firms need to manage the paradox related to the three knowledge management processes in order to stimulate innovation within the ecosystem. Moreover, the lead firm needs to systematically socialize new firms joining the ecosystem in order to ensure that these new members embrace the value and culture of the paradox of opposing forces.

Theoretical implications

Our approach to knowledge management capabilities in innovation ecosystems has three theoretical implications. First, Day (1994) usefully classified capabilities into three types, namely outside-in, inside-out, and spanning processes. We showed that one aspect of such capabilities relates to knowledge management capabilities that enhance innovation within an ecosystem 
setting. In order for knowledge management capabilities of the lead firm to work effectively, other capabilities need to be evident as well. For example, the research and development capability of the firms in the ecosystem needs to interact with the knowledge management capability in order to make them effective. This has implications in terms of the extent to which the knowledge management capabilities relate to incremental, as opposed to radical, innovation. In particular, how might the knowledge management capabilities discussed enhance one type of innovation at the expense of another.

Second, the marketing literature has identified a myriad of possible network organizational structures. The managed network organizations "promise superior information processing, knowledge creation, and adaptive properties to conventional firms" (Achrol and Kotler 1999, p. 161). The enhanced marketing capability needs to orchestrate the capabilities of the network partners. Such enhanced capabilities call for greater emphasis on relational capabilities that extend the firm's resources beyond its boundaries and enable access to the resources of network partners (Dyer and Singh 1998; Vargo and Lusch 2011). Marketing scholars have recognized the importance of relational capabilities (Heide and Wathne 2006). However, the focus has been on the relational types and the appropriate governance mechanisms. Although the literature recognizes the importance of governance within multiple dyads and networks, it has not explicated the capabilities that firms need to develop in such network-based organizations (Wathne and Heide 2004). Our study on knowledge management capabilities has implications for developing further the relational capabilities within such networked organizational structures.

Third, the knowledge management capabilities have potential implications for the type of knowledge that might influence innovation outcomes. In particular, there is both explicit and 
tacit knowledge that could influence innovation outcomes. The knowledge management capabilities could have different implications and efficiency considerations in processing these two types of knowledge. The absorptive capacity could play a crucial role here, as it relates to the extent to which the partner firms can actually process and make sense of the knowledge being generated. Therefore, the absorptive capacity of member firms within the ecosystem could influence the effectiveness of the lead firm's knowledge management capabilities on innovation outcome for the ecosystem. Our study has implications for understanding the relationship between the lead firm's role, as outlined by the propositions and the absorptive capacity of the partner firms, and hence the innovation outcomes of the ecosystem.

Finally, a natural follow-up implication of our study is the need to empirically test the propositions. One way to do this is to identify the major ecosystems of firms across various industries and conduct a survey to measure the constructs. The dependent variable is the rate of innovation of the ecosystem, which can be measured as the percentage of sales of the ecosystem from new product/services or the number of new business models developed by ecosystem members. The explanatory variables involve asking questions related to open and closed action strategies for each of the three knowledge processes. This could be done using a 7-point Likerttype response scale. For example, for knowledge acquisition, autonomy-related items could include "The lead firm gives a lot of autonomy in deciding which other firms can join the ecosystem" and control-related items could include "The lead firm sets many rules for member firms to move between different partnership tiers." Various control variables need to be collected, including size of the ecosystem, age, industry, and so on. One of the challenges in testing the propositions empirically is selection bias, in other words, whether firms with certain unobservable characteristics are joining the ecosystem and hence influencing the outcome. These 
issues need to be addressed by identifying the appropriate instrumental variables to help identify the effects.

\section{Conclusions}

Globalization, the intensity of technological change, and the shift in industry borders are shaping organizational innovation (Easterby-Smith, Lyles and Tsang 2008; Norman 2002). As a result, innovation is increasingly pursued by a loosely coupled community of highly specialized firms that are united in their desire to serve specific customer needs (Achrol 1991; 1997; Dhanaraj and Parkhe 2006). In this paper, we identify the key knowledge management routines of the lead firm by managing the tension inherent in team based innovation, which provides a framework for managers to enhance the rate of innovation in an ecosystem.

It is noteworthy to acknowledge boundary conditions for the knowledge management capabilities of the lead firm, which are more valuable in some situations than in others. First, the knowledge management capabilities of the lead firm are suitable in cases where knowledge is the principal form of economic resource. In such markets, there is often a tradeoff between the benefits of discovery as a result of having an ecosystem of firms and divergence costs resulting from the need to coordinate (Boudreau 2010). The proposed routines for the knowledge management capabilities of the lead firm prescribed in this paper would better enable the firm to balance these two tensions in being able to respond to changes in the environment.

Second, the benefit of the knowledge management capabilities of the lead firm we propose in a knowledge-based economy is often more valuable when there are market and technological changes. However, as discussed earlier, firms are more likely to collaborate when there is a reasonable amount of certainty in terms of the output and how it will be shared. This tradeoff could vary based on different factors, for example, whether the industry is in its early 
stages of growth, or if the proposition is for the platform or complementary products. Firms in the early stages of development face significant uncertainty bordering on an ambiguous environment. Therefore, lead firms operating in the early stages of technology might find it more difficult to implement the knowledge management capabilities as a result of the highly ambiguous environment. However, as technology develops often the level of ambiguity reduces with continued opportunities for innovation. This provides the basis for embracing the propositions of the knowledge management capabilities of the lead firm, as articulated in this paper.

This paper contributes by extending the concept of the knowledge management capabilities of the lead firm within an innovation ecosystem. As such, it provides a useful starting point for the much-needed conceptual foundation for future research in this area. Opportunities are manifold and include further theoretical work that elaborates a series of propositions pertaining to the antecedents, consequences and moderators for the knowledge management capabilities of the lead firm. A natural extension is empirical work to develop propositions and hypotheses for measuring and testing of such knowledge management capabilities. Similarly, we call for in-depth qualitative studies that seek to uncover the complex micro-processes associated with the development, maintenance, and exercise of these knowledge management capabilities of the lead firm. Pursuing any or all of these avenues may be a worthwhile undertaking given the rise of the ecosystem as an increasingly important locus of innovation. We believe our paper provides the foundation for a better understanding of the knowledge management capabilities needed for being more market-focused in a collaborative environment. 


\section{References}

Achrol, R. S. (1991). Evolution of the marketing organization: New forms for turbulent environments. Journal of Marketing, 55(4), 77-93.

Achrol, R. S. (1997). Changes in the theory of inter-organizational relations in marketing: Toward a network paradigm. Journal of the Academy of Marketing Science, 25(1), 5671.

Achrol, R. S., \& Kotler, P. (1999). Marketing in the network economy. Journal of Marketing, $146-163$.

Adner, R. (2006). Match your innovation strategy to your innovation ecosystem. Harvard Business Review, 84(4), 98-107.

Adner, R, \& Kapoor, R. (2010). Value creation in innovation ecosystems: How the structure of technological interdependence affects firm performance in new technology generations. Strategic Management Journal, 31, 306-333.

Allison, K. (2008). Facebook leads MySpace in unique visitors. Financial Times, June, 23 edition.

Alper, S., Tjosvold, D., \& Law, K. S. (2000). Conflict management, efficacy and performance in organizational teams. Personnel Psych., 53, 625-642.

Ancona, D. G., \& Caldwell, D. F. (1992). Bridging the boundary: External activity and performance in organizational teams. Administrative Science Quarterly, 37, 634-665.

Ancori, B., Bureth, A., Cohendet, P. (2000). The economics of knowledge: The debate about codification and tacit knowledge. Industrial and Corporate Change, 9(2), 255-288.

Atuahene-Gima, K. (1995). An exploratory analysis of the impact of market orientation on new product performance: A contingency approach. Journal of Product Innovation Management, 12(4), 275-293.

Avadikyan, A., Llerena, P., Matt, M., Rozan, A., \& Wolff, S. (2001). Organisational rules, codification and knowledge creation in inter-organisation cooperative agreements. Research Policy, 30, 1443-1458.

Beal, D. J., Cohen, R. R., Burke, M. J., \& McLendon, C. L. (2003). Cohesion and performance in groups: A meta-analytic clarification of construct relations. J. Appl. Psych., 88, 9891004.

Boudreau, K. (2010). Open platform strategies and Innovation: Granting access vs. devolving control. Management Science, 56(10), 1849-1872.

Brandenburger, A. M., \& Nalebuff, B. J. (1997). Co-Opetition: A Revolution Mindset That Combines Competition and Cooperation: The Game Theory Strategy That's Changing the Game of Business. Currency: New York.

Bresman, H. (2010). External learning activities and team performance: A multimethod field study. Organization Science. 21(1) 81-96.

Brown, S. L., \& Eisenhardt, K. M. (1997). The art of continuous change: Linking complexity theory and time-paced evolution in relentlessly shifting organizations. Admin. Sci. Quart., $42,1-34$.

Bunderson, J. S., \& Sutcliffe, K. M. (2002). Comparing alternative conceptualizations of functional diversity in management teams: Process and performance effects. Acad. Management Journal, 45, 875-893.

Casadesus-Masanell, R., \& Ricart, J. E. (2010). From strategy to business models and onto tactics. Long Range Planning, 43(2-3), 195-215. 
Carvalho, M.M., Fleury, A., Lopes, A.P. (2013). An overview of the literature on technology roadmapping (TRM): contributions and trends. Technology Forecasting Social Change, 80, 1418-1437.

Caetano, M. \& D.C. Amaral, (2011). Roadmapping for technology push and partnership: a contribution for open innovation environments. Technovation, 31(7), 320-335.

Chatman, J. A., Polzer, J. T., Barsade, S. G., \& Neale, M. A. (1998). Being different yet feeling similar: The influence of demographic composition and organizational culture on work processes and outcomes. Admin. Sci. Quart., 43, 749-780.

Chesbrough, H. (2003). Open Innovation: The New Imperative for Creating and Profiting from Technology. Cambridge, MA: Harvard Business School Press.

Christensen, C. M., \& Bower, J. L. (1996). Customer power, strategic investment, and the failure of leading firms. Strategic Management Journal, 17(3), 197-218.

Clarysse, B., Wright, M., Bruneel, J. and Mahajan, A. (2014). Creating value in ecosystems: Crossing the chasm between knowledge and business ecosystems, Research Policy, 43, 1164-1176.

Crumley, Carole L. (1995). Heterarchy and the Analysis of Complex Societies. Archeological Papers of the American Anthropological Association, 6(1), 1-5.

Cyert, R. M., \& March, J. G. (1963). A Behavioral Theory of the Firm. Englewood Cliffs, NJ: Prentice Hall.

Dahlquist, S. H., \& Griffith, D. A. (2015). A framework for the formation of governance portfolios in international interfirm marketing collaborations. AMS Review, 5 (1-2), 4559.

Davis, J., \& Eisenhardt, K. (2011). Rotating leadership and collaborative innovation: Recombination processes and in symbiotic relationships, Administrative Science Quarterly, 56, 159-201.

Day, G. S. (1994). The capabilities of market-driven organizations. Journal of Marketing, 58(4), 37-52.

Day, G. S. (2011). Closing the marketing capabilities gap. Journal of Marketing, 75(4), 183-195.

Day, G. S., \& Schoemaker, P. J. H. (2004). Driving through the fog: Managing at the edge. Long Range Planning, 37(2), 127-142.

De Dreu, C. K. (2002). Team innovation and team effectiveness: The importance of minority dissent and reflexivity, European Journal of Work and Organizational Psychology, 11(3), 285-298.

De Dreu, C. K. W., \& Weingart, L. R. (2003). Task versus relationship conflict, team performance and team member satisfaction: A meta-analysis. J. Appl. Psych., 88, 741-749.

De Rond, M. (2008). Teams: lessons from the Oxford and Cambridge Boat Race. Harvard Business Review, 86(9), 28

Denrell, J., Fang, C., \& Winter, S. G. (2003). The economics of strategic opportunity. Strategic Management Journal, 24(10) (October), 977-990.

Dhanaraj, C., \& Parkhe, A. (2006). Orchestrating innovation networks. Academy of Management Review, 31(3), 659-669.

Dodgson, M., Gann, D., \& Salter, A. (2006). The role of technology in the shift towards open innovation: The case of Procter \& Gamble. R\&D Management, 36(3) (6), 333-346. doi:10.1111/j.1467-9310.2006.00429.x.

Dougherty, D. (2006). Organizing innovation in the $21^{\text {st }}$ century. In Clegg, Hardy, Lawrence, \& Nord (eds.), The Sage Handbook of Organization Studies, Sage Publications, London, 
598-617.

Doz, Y and M. Kosonen. (2010). Embedding strategic agility, Long Range Planning, 43, 370382.

Dutton, J. E., Ashford, S. J., O'Neill, R. M., Hayes, E., \& Wierba, E. E. (1997). Reading the wind: How middle managers assess the context for selling issues to top managers. Strategic Management Journal, 18(5), 407-423.

Dutton, J. E., Ashford, S. J., O'Neill, R. M., \& Lawrence, K. A. (2001). Moves that matter: Issue selling and organizational change. Academy of Management Journal, 44(4), 716-736.

Dyer, J. H., \& Hatch, N. W. (2006). Relation-specific capabilities and barriers to knowledge transfers: Creating advantage through network relationships. Strategic Management Journal, 27(8) (8), 701-719. doi:10.1002/smj.543.

Dyer, J. H., \& Singh, H. (1998). The relational view: Cooperative strategy and sources of interorganizational competitive advantage. Academy of Management Review, 23(4), 660-679.

Easterby-Smith, M., Lyles, M. A., \& Tsang, E. W. K. (2008). Inter-organizational knowledge transfer: Current themes and future prospects. Journal of Management Studies, 45(4), 677-690.

Gawer, A., \& Cusumano, M. A. (2008), How companies become platform leaders, MIT Sloan Management Review, 49(2), 28-35.

Gawer, A., Cusumano, M. A. (2014), Industry platforms and ecosystem innovation. Journal of Product Innovation Management, 31(3), 417-433.

Grant, R. M., \& Baden-Fuller, C. (2004). A knowledge accessing theory of strategic alliances. Journal of Management Studies, 41(1), 61-84.

Gebert, D., Boerner, S., \& Kearney, E. (2010). Fostering team innovation: Why is it important to combine opposing action strategies? Organization Science, 21(3) 593-608.

Gulati, R., Puranam, P., \& Tushman, M. (2012). Meta-organization design: Rethinking design in organization in interorganizational and community context, 33, 571-586.

Han, J. K., Kim, N., \& Srivastava, R. K. (1998). Market orientation and organizational performance: Is innovation a missing link? Journal of Marketing, 62(4), 30-45.

Hannan, M. T., \& Freeman, J. (1984). Structural inertia and organizational change. American Sociological Review, 49(2), 149-164.

Hedlund, G. (1986), The Hypermodern MNC-A Heterarchy?, Human Resource Management, 25(1), 9-25.

Heide, J. B. (1994). Interorganizational Governance in Marketing Channels, Journal of Marketing, 58, 71-85.

Heide, J., \& Wathne, K. H. (2006) Friends, Businesspeople, and Relationship Roles: A Conceptual Framework and A Research Agenda, Journal of Marketing, 70(July), 90-103.

Heiman, B.A. \& Neikerson, J.A. (2004) Empirical Evidence Regarding the Tension Between Knowledge Sharing and Knowledge Expropriation in Collaborations, Managerial and Decision Economics, 25, 401-420.

Heiman, B.A. and J.A. Nickerson. (2004) Empirical Evidence Regarding the Tension between Knowledge Sharing and Knowledge Expropriation in Collaboration, Managerial and Decision Economics, 25(6-7), 401-420.

Henderson, R. M., \& Clark, K. B. (1990). Architectural innovation: The reconfiguration of existing product technologies and the failure of established firms. Administrative Science Quarterly, 35(1), 9-30.

Hess, C., \& Ostrom, E. (2007). Understanding Knowledge as a Commons - From Theory to 
Practice. Cambridge: Massachusetts Institute of Technology.

Hult, G. T. M. (2011). Toward a theory of the boundary-spanning marketing organization and insights from 31 organization theories. Journal of the Academy of Marketing Science, 39: 509-536.

Hurley, R. F., \& Hult, G. T. M. (1998). Innovation, market orientation, and organizational learning: An integration and empirical investigation. Journal of Marketing, 62(4), 42-54.

Iansiti, M., \& Levien, R. (2004), Strategy as ecology, Harvard Business Review, 82(3), 1-10.

Itami, H., \& Nishino, K. (2010). Killing two birds with one stone, Long Range Planning, 43, 364-369.

Jackson, S. E., Joshi, A., \& Erhardt, N. L. (2003). Recent research on team and organizational diversity: SWOT analysis and implications. Journal of Management, 29, 801-830.

Johnson, M. W., Christensen, C. M., \& Kagermann, H. (2008). Reinventing your business model. Harvard Business Review, 86(12), 50-59.

Kaplan, S. (2008). Framing contests: Strategy making under uncertainty. Organization Science, 19(5), 729-752.

Katila, R., \& Ahuja, G. (2002) Something old, something new: A longitudinal study of search behavior and new product introduction. Academy of Management Journal, 45, 11831194.

Katz, R. (1982). The effects of group longevity on project communication and performance. Admin. Sci. Quart., 27, 81-104.

Keller, R. T. (1994). Technology-information processing fit and the performance of R\&D project groups: A test of contingency theory. Academy of Management Journal., 37, 167-179.

Kohli, A. K, \& Jaworski, B. J. (1990). Market orientation: The construct, research propositions, and managerial implications. Journal of Marketing, 54(2), 1-18.

Leten, B., Vanhaverbeke, W.,Roijakkers, N.,Clerix, A., Van Helleputte, J.,(2013) IP models to orchestrate innovation ecosystems: IMEC a public research institute in nano electronics. California Management Review. 4, 51-64.

Lewis, M. W., M. A. Welsh, G. E. Dehler, \& S. G. Green. 2002. Product development tensions: Exploring contrasting styles of project management. Academy of Management Journal. 45 546-564.

Lichtenthaler, U., (2011). Open innovation: past research, current debates, and future directions. Academy of Management Perspectives 25 (1), 75-93.

Luca, L. M. D., \& Atuahene-Gima, K. (2007). Market knowledge dimensions and crossfunctional collaboration: Examining the different routes to product innovation performance. Journal of Marketing, 71(1), 95-112.

Lusch, R., Vargo, S. L., \& Tanniru, M. (2010). Service, value networks and learning. Journal of the Academy of Marketing Science, 38(1), 19-31.

March, J. G., \& Shapira, Z. (1987). Managerial perspectives on risk and risk taking. Management Science, 33(11), 1404-1418.

Mathieu, J, Goodwin, G. Heffner, T., Salas, E., \& Canon-Bowers, A. (2000). The influence of mental models on team process and performance, J. of Applied Phycology, 85, 273-283.

Martins, L, Rindova, V. and Greenbaum, B. (2015). Unlocking the hidden value of concepts: A cognitive approach to business model innovation, Strategic Entrepreneurship Journal, forthcoming.

McCulloh, W.S. (1945) A heterarchy of values determined by a topology of nervous nets, Bull Math. Biophysics, 7, 89-93. 
McGrath, R. G. (2010). Business models: A discovery driven approach. Long Range Planning, $43(2-3)$ 247-261.

Moore, J. (2006). Business ecosystems and the view from the firm. Antitrust Bulletin, 51(1), 3175.

Nambisan, S., \& Sahwney, M. (2011). Orchestration processes in network centric innovation. Academy of Management Perspectives, (August), 40-57.

Norman, P. M. (2002). Protecting knowledge in strategic alliances: Resource and relational characteristics. The Journal of High Technology Management Research, 13(2), 177-202.

Obstfeld, D. (2005). Social networks, the tertius iungens orientation, and involvement in innovation. Admin. Sci. Quart., 50, 100-130.

Ocasio, W. (1997). Towards an attention-based view of the firm. Strategic Management Journal, 18(1), 187-206.

Olstrom, E. (2010). Beyond Markets and States: Polycentric Governance of Complex Economic Systems, American Economic Review, 100, 641-672.

Penrose, E. T. (1959). The Theory of the Growth of the Firm. New York: John Wiley.

Prahalad, C. K., \& Krishnan, M. S. (2008). The new age of innovation: Driving co-created value through global networks. New York: McGraw-Hill Professional.

Reagans, R., \& Zuckerman, E. W. 2001. Networks, diversity, and productivity: The social capital of corporate R\&D teams. Organization Science, 12(4) 502-517.

Richard, P. J., \& Devinney, T. M. (2005). Modular strategies: B2B technologies and Architectural knowledge. California Management Review, 47(4), 86-113.

Rohrbeck, R. (2010). Harnessing a network of experts for competitive advantage: technology scouting in the ICT industry, Research Technology Management, 40(2), 169-180.

Rosenkopf, L., \& Nerkar, A. (2001). Beyond local search: Boundary-spanning, exploration, and impact in the optical disk industry. Strategic Management Journal, 22(4), 287-306.

Rousseau, D. M., Sitkin, S. B., Burt, R. S., \& Camerer, C. (1998). Not so different at all: A cross-discipline view of trust. Academy of Management Review, 23, 393-404.

Sanchez, R., \& J. Mahoney (1996). Modularity, Flexibility and Knowledge Management in Product and Organizational design, Strategic Management Journal, 17, 63-76.

Seo, M. G., Putnam, L. L., \& Bartunek, J. M. (2004). Dualities and tensions of planned organizational change. In M. S. Poole, \& A. H. Van de Ven (eds.), Handbook of Organizational Change and Innovation, Oxford University Press, New York.

Sheremata, W. A. (2002). Finding and solving problems in software new product development. J. Product Innovation Management, 19, 144-158.

Simons, T., Pelled, L., \& Smith, K. (1999). Making use of difference: Diversity, debate and decision comprehensiveness in top management teams, Academy of Management Journal, 42, 662-673.

Sinkula, J. M. (1994). Market information processing and organizational learning. Journal of Marketing, 58(1), 35-45.

Slater, S. F, \& Narver, J. C. (1995). Market orientation and the learning organization. Journal of Marketing, 59(3), 63-74.

Slowinski, G., Hummel, E., Gupta, A., \& Gilmont, E. R. (2009). Effective practices for sourcing innovation. Research Technology Management, 52(1), 27-34.

Smith, W. K., Binns, A., \& Tushman, M. L. (2010). Complex business models: Managing strategic paradoxes simultaneously. Long Range Planning, 43(2-3), 448-461. 
Smith, W., \& Lewis, M. (2011) Toward a theory of paradox: A dynamic equilibrium model of organizing. Acad. Management Review, 36(2), 381-403.

Snow, C. C., Fjeldstad, Ø. D., Lettl, C., \& Miles, R. E. (2011). Organizing continuous product development and commercialization: The collaborative community of firms model. Journal of Product Innovation Management, 28(1): 3-16.

Sosna, M., Trevinyo-Rodriguez, R. N., \& Velamuri, S. M. (2010). Business model innovation through trial and error learning. Long Range Planning, 43(2-3), 383-407.

Stabell, C., \& Fjeldstad, O. (1998). Configuring value for competitive advantage: On chains, shops and networks, Strategic Management Journal, 19, 413-437.

Teece, D. J. (2007). Explicating dynamic capabilities: The nature and microfoundations of (sustainable) enterprise performance. Strategic Management Journal, 28(13), 1319-1350.

Teece, D. J. (2010). Business models, business strategy and innovation. Long Range Planning, 43(2), 172-194.

Thomas, L., Autio, E, \& Gann, D. (2014). Architectural leverage: Putting platform in context, Academy of Management Perspectives, 28(2), 198-219.

Tiwana, T. (2002). The Knowledge Management Toolkit: Orchestrating It, Strategy and Knowledge Platforms, Prentice Hall.

Vargo, S., \& Lusch, R. (2004). Evolving to a new dominant logic for marketing, Journal of Marketing, 68, 1-17.

Vargo, S., \& Lusch, R. (2011). It's all B2B... and beyond: Toward a systems perspective of the market. Industrial Marketing Management, 40, 181-187.

Velu, C., \& Stiles, P. (2013) Managing decision-making and cannibalization for parallel business models, Long Range Planning, 43, 443-458.

Velu, C. (2015). Business model innovation and third-party alliance on the survival of new firms, Technovation, 35, 1-11.

Von Hippel, E., \& Krogh, G. V. (2003), Open source software and the private collective innovation model: Issues for Organization Science, Organization Science, Organization Science, 14(2), 208-223.

Wareham, J, Fox, P., \& Giner, J. (2014). Technology ecosystem governance. Organization Science, 25(4), 1195-1215

Wathne, K. H., \& Heide, J. (2004). Relationship Governance in a Supply Chain Network, Journal of Marketing, 68(January), 73-89.

Weick, K. E. (1976). Educational organizations as loosely coupled systems. Administrative Science Quarterly, 21(1), 1-19.

Wernerfelt, B. (1984). A resource-based view of the firm. Strategic Management Journal, 5(2), 171-180.

Williamson, P.J. \& de Meyer, A. (2012). Ecosystem advantage: How to successfully harness the power of partners? California Management Review, 55(1), 24-46.

Yadav, M.S. (2010). The Decline of Conceptual Articles and Implications for Knowledge

Development. Journal of Marketing, 74 (1), 1-20.

Zahra, S., \& Nambisan, S. (2011). Entrepreneurship in Global Innovation Systems, AMS Review, $1,4 \_17$. 


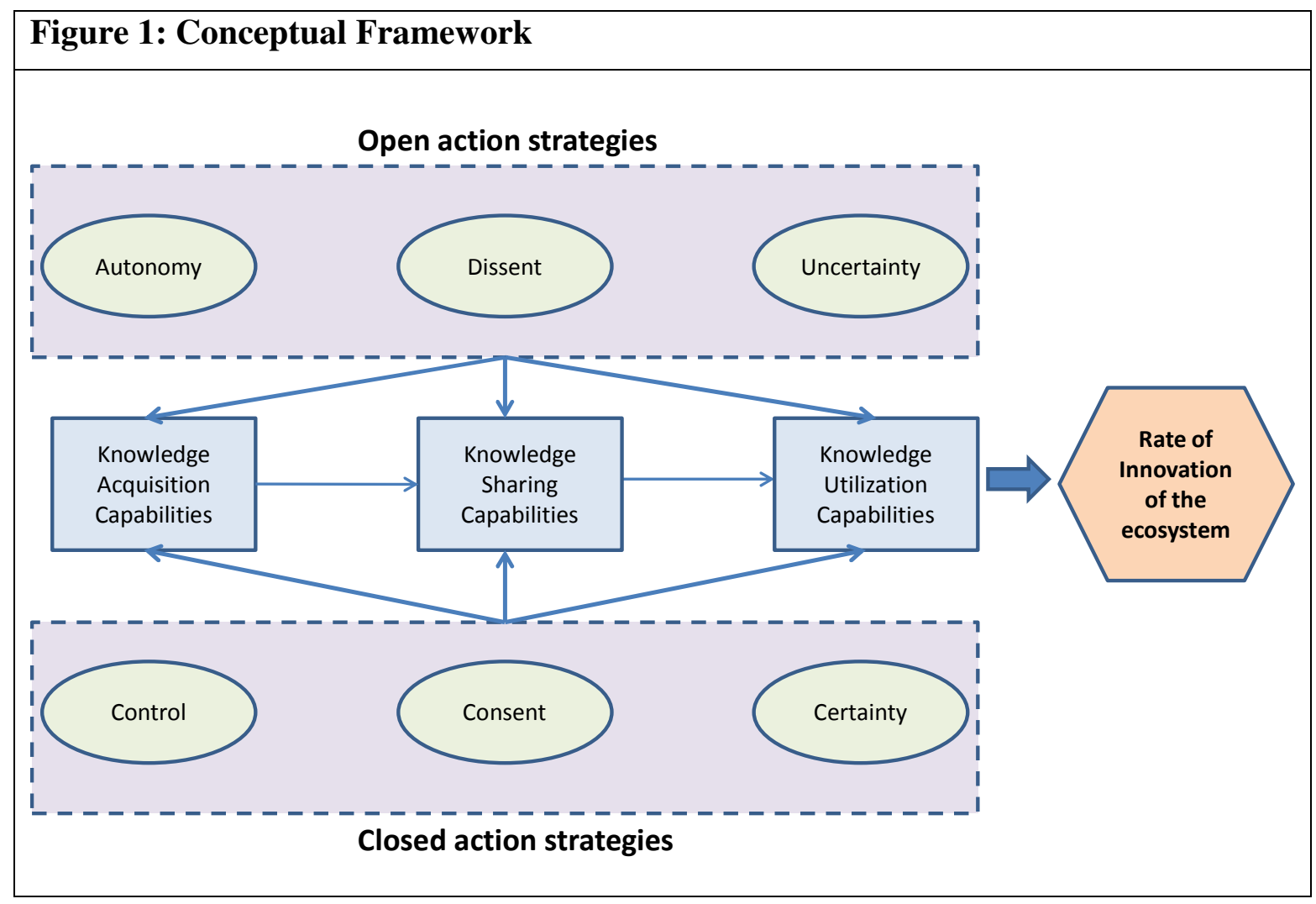


Table 1: Summary of Open Action and Closed Action Strategies

\begin{tabular}{|c|c|c|}
\hline Dimension & Open Action Strategies & Closed Action Strategies \\
\hline $\begin{array}{l}\text { Anthropological: } \\
\text { Autonomy vs. } \\
\text { Control }\end{array}$ & $\begin{array}{l}\text { Facilitating decentralization and } \\
\text { empowerment among team } \\
\text { members in order to expand the } \\
\text { range of possibilities. }\end{array}$ & $\begin{array}{l}\text { Instituting more directive control } \\
\text { on team members by specifying } \\
\text { rules and regulations in order to } \\
\text { coordinate the action plans. } \\
\text { Example: Enforcing time and } \\
\text { budget constraints and having } \\
\text { frequent feedback with team } \\
\text { members in order to curtail } \\
\text { freedom and manage the } \\
\text { coordination of action plans. }\end{array}$ \\
\hline $\begin{array}{l}\text { Social: Dissent vs. } \\
\text { Consent }\end{array}$ & $\begin{array}{l}\text { Facilitating open } \\
\text { communication, debate and } \\
\text { disagreement necessitates a } \\
\text { variety of views. } \\
\text { Example: Fostering constructive } \\
\text { and compelling discussion of } \\
\text { issues among team members } \\
\text { without curtailing their } \\
\text { enthusiasm in order to bring out } \\
\text { a variety of views. }\end{array}$ & $\begin{array}{l}\text { Promoting collectivist culture } \\
\text { and team homogenizing in order } \\
\text { to enhance consensus potential. } \\
\text { Example: Promoting informal } \\
\text { communication outside formal } \\
\text { meetings in order to achieve } \\
\text { cohesion, harmony and trust. }\end{array}$ \\
\hline $\begin{array}{l}\text { Epistemological" } \\
\text { Uncertainty vs. } \\
\text { Certainty }\end{array}$ & $\begin{array}{l}\text { Facilitating knowledge exchange } \\
\text { with external entities in order to } \\
\text { foster and evolve new } \\
\text { knowledge. } \\
\text { Example: Encouraging team } \\
\text { members or selecting specific } \\
\text { team members to interact with } \\
\text { the people/organizations outside } \\
\text { the immediate team in order not } \\
\text { to be constrained by the existing } \\
\text { mindset. }\end{array}$ & $\begin{array}{l}\text { Promoting internal team } \\
\text { communication and utilizing } \\
\text { existing knowledge in order to } \\
\text { consolidate new and existing } \\
\text { knowledge. } \\
\text { Example: Encouraging team } \\
\text { members to rely on known } \\
\text { knowledge among themselves in } \\
\text { order to have a common } \\
\text { standard of evaluation and a } \\
\text { stable shared task model. }\end{array}$ \\
\hline
\end{tabular}


Table 2: Summary of Knowledge Management Capabilities

\begin{tabular}{|c|c|c|c|}
\hline $\begin{array}{l}\text { Knowledge } \\
\text { Management } \\
\text { Capabilities }\end{array}$ & Propositions & Open Action Strategy & Closed Action Strategy \\
\hline \multirow[t]{3}{*}{$\begin{array}{l}\text { Knowledge } \\
\text { Acquisition }\end{array}$} & $\begin{array}{l}\text { 1a: } \\
\text { Autonomy vs. } \\
\text { Control }\end{array}$ & $\begin{array}{l}\text { Adopting open access } \\
\text { membership through } \\
\text { stratified tiering }\end{array}$ & $\begin{array}{l}\text { Implementing graduated } \\
\text { controls across the tiered } \\
\text { membership }\end{array}$ \\
\hline & $\begin{array}{l}\text { 1b: } \\
\text { Dissent vs. } \\
\text { Consent }\end{array}$ & $\begin{array}{l}\text { Bringing diverse partner } \\
\text { firms together in order to } \\
\text { interact face-to-face or } \\
\text { through virtual } \\
\text { communities }\end{array}$ & $\begin{array}{l}\text { Giving greater } \\
\text { responsibilities to higher } \\
\text { tiered partners to help } \\
\text { identify issues that are key } \\
\text { to the collective good of the } \\
\text { ecosystem }\end{array}$ \\
\hline & $\begin{array}{l}\text { 1c: } \\
\text { Uncertainty } \\
\text { vs. Certainty }\end{array}$ & $\begin{array}{l}\text { Sourcing external } \\
\text { information }\end{array}$ & Using internal information \\
\hline \multirow[t]{3}{*}{$\begin{array}{l}\text { Knowledge } \\
\text { Sharing }\end{array}$} & $\begin{array}{l}\text { 2a: } \\
\text { Autonomy vs. } \\
\text { Control }\end{array}$ & $\begin{array}{l}\text { Embracing decision } \\
\text { openness for component } \\
\text { knowledge dissemination }\end{array}$ & $\begin{array}{l}\text { Adopting control through } \\
\text { dissemination of } \\
\text { architectural knowledge }\end{array}$ \\
\hline & $\begin{array}{l}\text { 2b: } \\
\text { Dissent vs. } \\
\text { Consent }\end{array}$ & $\begin{array}{l}\text { Building reflexivity } \\
\text { among partner firms }\end{array}$ & $\begin{array}{l}\text { Providing assurance of not } \\
\text { leveraging power from } \\
\text { information asymmetries in } \\
\text { knowledge sharing activities }\end{array}$ \\
\hline & $\begin{array}{l}\text { 2c: } \\
\text { Uncertainty } \\
\text { vs. Certainty }\end{array}$ & Adopting fuzzy rules & Adopting codified rules \\
\hline \multirow[t]{3}{*}{$\begin{array}{l}\text { Knowledge } \\
\text { Utilization }\end{array}$} & $\begin{array}{l}\text { 3a: } \\
\text { Autonomy vs. } \\
\text { Control }\end{array}$ & $\begin{array}{l}\text { Enabling partner firms to } \\
\text { decide on how to } \\
\text { recombine their assets to } \\
\text { develop the new business } \\
\text { model }\end{array}$ & $\begin{array}{l}\text { Acting as an integrator to } \\
\text { design the platform } \\
\text { architecture }\end{array}$ \\
\hline & $\begin{array}{l}\text { 3b: } \\
\text { Dissent vs. } \\
\text { Consent }\end{array}$ & $\begin{array}{l}\text { Encouraging renewal of } \\
\text { the dominant logic of the } \\
\text { existing business model }\end{array}$ & $\begin{array}{l}\text { Reconciling differences in } \\
\text { the cognitive aspect of the } \\
\text { business model design and } \\
\text { providing decisive } \\
\text { leadership when differences } \\
\text { prevail }\end{array}$ \\
\hline & $\begin{array}{l}\text { 3c: } \\
\text { Uncertainty } \\
\text { vs. Certainty }\end{array}$ & $\begin{array}{l}\text { Grafting business models } \\
\text { from outside }\end{array}$ & $\begin{array}{l}\text { Recombining existing } \\
\text { business models and acting } \\
\text { as the overall architect in } \\
\text { managing risks }\end{array}$ \\
\hline
\end{tabular}




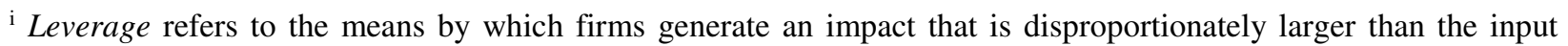
required in order to create value and, hence, competitive advantage. Leverage could imply production leverage to achieve economies of scale and scope, transaction leverage to achieve transaction efficiency through pricing and market access, or innovation leverage to achieve the economics of innovation to facilitate the creation of new goods/services or business models (Thomas, Autio and Gann 2014). The focus of this paper is on innovation leverage.

ii The term platform has been used in a variety of contexts. For example, the organizational context views a platform as organizational capabilities that enable superior performance; the product family context views a platform as a stable centre of family of products to enable derivative products; the market intermediary context views a platform as an intermediary between parties to a market based exchange; and, finally, the platform ecosystems context views a platform as a system that supports a collection of complementary assets (Thomas, Autio and Gann 2014, p.200). Our use for the purposes of this paper is similar to the platform ecosystems context.

iii Some studies extend the notion of a platform to include network effects where there are demand side network externalities (Gawer and Cusumano 2014). Demand side network externalities imply that as more users adopt the platform, the platform becomes more valuable to other users. Demand side network externalities are not key to our use of the term in this paper.

iv The literature has used various terms such as lead firm, hub firm, network orchestrator, and keystone firm, among others. We use "lead firm" to denote leadership in the ecosystem.

$v$ This case vignette is based on author's own interviews with ARM Holdings PLC. 